\title{
Is Foreign Direct Investment Effective From The Perspective Of Tax Avoidance? An Analysis Of Tax Avoidance Through The International Transfer Pricing Behaviors Of Korean Corporations
}

\author{
Sung Jin Park, Sungshin Women's University, South Korea \\ Woo Jin Park, Yonseil University, South Korea \\ Eun Jung Sun, Hannam University, South Korea \\ Sohee Woo, Woosong University, South Korea
}

\begin{abstract}
This study examines whether multinational companies carry out tax avoidance through subsidiaries. An empirical analysis was conducted of 4,585 Korean firms from 2001 to 2010 by company and year. The results are as follows. First, MNCs that have become more internationally diversified through the establishment of overseas subsidiaries generally show a higher tendency to avoid tax. Thus, the analysis results show a positive correlation between globally diversified MNCs and corporate tax avoidance. This correlation is established due to the firms' active use of tax strategies (investment tax credits, tax cuts) applicable to the various countries in which they have expanded their businesses. Second, the analysis results showed that these firms actively avoided tax with overseas transfer pricing behaviors when compared to companies without overseas subsidiaries. Thus, the adjustment of sales prices and purchase value through actual transactions increased the propensity of the parent company to avoid tax.

This study holds significance in that it showed how foreign direct investment and overseas transfer pricing strategies through foreign subsidiaries can be used by companies to avoid tax. This also explains why multinational companies are recently increasing their efforts by building additional local production factories. In this sense, this study has important implications that should be noted by national governments hoping actively to attract companies in the future.
\end{abstract}

Keywords: Transfer Pricing Behavior; Tax Avoidance; FDI (Foreign Direct Investment); Overseas Subsidiary; MNC (Multinational Company)

\section{INTRODUCTION}

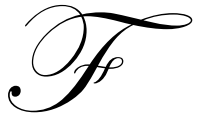

oreign direct investment (hereafter, FDI) through an overseas subsidiary can be defined as a company's expansion into a new, less exploited market (Kogut 1983). Firms can expect various positive effects through FDI. First, there is the investment portfolio effect. The loss sustained in a market with poor performance can be offset by the profits generated in another market (Kogut 1985). The second effect is a localization strategy. Market-appropriate investment decisions can lower risk while facilitating efficient management (Denis et al. 2002). Third, knowledge and experiences accumulated in various markets can be used to enhance the value of intangible assets such as manufacturing technologies, marketing techniques and management abilities, which will in turn increase firm value (Hitt et al. 1997; Morck and Yeung 1998; Craig and Douglas 2000; Geringer et al. 2000).

Furthermore, FDI can produce benefits in terms of tax laws. In an effort to attract investment, many countries, developed and developing nations alike, have recently started to offer investment tax credits to foreign companies. 
In this sense, the importance of such tax-related effects has increased. Therefore, in-depth research on this and related subjects is required.

The 2014 "Fortune Global 500" list of the world's largest corporations includes 17 Korean firms, including Samsung Electronics. Most of the listed companies are headquartered in the U.S., but the numbers of firms in emerging markets such as China (ranked second) and Korea have increased significantly, climbing to parity with those based in Western Europe or the U.S. This implies that FDI is no longer an act limited to advanced countries; emerging market countries are now moving beyond their local market to invest actively in both developed and developing nations. This also signifies the greater importance of analyzing emerging market nations.

Studies which examine the effect of FDI through overseas subsidiaries on corporate tax avoidance have mostly focused analyses on corporations that are headquartered in an advanced country (Desaia and Dharmapala 2006, Desaia and Dharmapala 2009, Rossing 2013). Thus, the firms surveyed in these studies were mostly companies that were established in developed countries but which invested in other nations with a lower tax rate in an effort to reduce their tax burden. However, the case of Korea is rather unique as the country actively invests in other nations, such as the U.S. or various countries in Europe, despite the fact that its tax rate is generally lower than those of advanced countries. As this study analyzes the effect of FDI through overseas subsidiaries on the manager's propensity to avoid tax by studying Korean companies, which have the traits of both developed and emerging markets, it holds empirical significance which differs from that of precedent studies. In particular, this study has important implications for Korean firms that are faced with limitations in domestic market growth, unlike companies in the U.S. or Europe, and that must continuously increase FDI through overseas subsidiaries and transfer the relevant models to developing countries in the future.

Furthermore, earlier studies related to FDI or tax law were mostly focused on tax rates and investment, whereas tax havens have been the main topic of research on tax avoidance. Although there has been sufficient theoretical research on tax avoidance through normal transactions, few researchers have conducted empirical analyses on these and related matters. Studies that have carried out empirical analyses on relatively less advanced nations are especially rare.

This study used the traditional measurement of tax avoidance (GAAP ETR) and the D\&D (2006) model to verify the effect of tax avoidance through FDI. Robustness is also verified through the W\&L model.

The composition of this study is as follows. In Chapter 2, previous literatures are examined and the research hypotheses are established. Chapter 3 elaborates on the research design and thus the research methods and materials. Chapter 4 summarizes the empirical results, whereas Chapter 5 verifies the robustness of the empirical analysis. Lastly, Chapter 6 presents the conclusion, contributions and limitations of the study results.

\section{PRECEDENT STUDIES AND RESESARCH HYPOTHESIS}

\subsection{Precedent Studies}

\subsubsection{Foreign Direct Investment}

The possession of an overseas subsidiary is one way firms can carry out FDI (foreign direct investment). Related studies can be largely classified into those that study the effects of FDI-based global diversification on firm value, the cost of equity capital, sales performance, and corporate tax rates. First, in relation to global diversification and firm value, Errunza and Senbet (1981) find that corporations more diversified on a global scale tend to have a higher firm value, as they gain exclusive profits by harnessing the imperfections of the local capital market. Furthermore, Jung (2003) examines a positive relation between the level of global diversification and corporate sales performance, as measured by market share, market development and product sales.

On the other hand, Harris et al. (1982) argue that as companies become more diversified internationally, it worsens the issue of information asymmetry between the head office and the overseas branch, which in turn increases the costs related to corporate decision-making and reduces the value of the company. Similarly, Denis et al. (2002) find 
that firm value will decrease as a company becomes more globally diversified becomes due to inefficient investments made in different business units. In addition, Lee (2003) posits that there is a negative relation between global diversification and company value, as the firm must pay additional expenses to adapt to the local circumstances of the relevant country.

There are also studies that centered their analysis on the cost of equity capital from among various factors that influence firm value due to the lack of consistent empirical findings regarding the relation between global diversification and firm value. For example, Hughes et al. (1975) posit that as a company becomes more diversified, they experience a simultaneous decrease in both systematic and non-systemic risks. Similarly, Jiang et al. (2008) find that global diversification significantly reduces the cost of equity. However, according to Yoo et al. (2010), the cost of equity increases with greater diversification, as firms carrying out sales activities in various nations incur higher levels of sales risk triggered by exchange rate fluctuations and political instability.

Meanwhile, recent empirical findings have been released on the effect of international diversification on manager's earnings management. Jiraporn et al. (2008) examine a negative relation between firm's level of international diversification and the level of earnings management. They posit that the more internationally diversified a firm becomes, the greater reduction becomes in the volatility of company earnings, along with incentives for earnings management. Similarly, Ahn et al. (2012) also find that international diversification is negatively related with the level of earnings management by the firm. Meanwhile, El Mehdi and Seboui (2011) examine that the level of earning management by a firm increases when the company becomes more internationally diversified because the manager of a globally diversified firm manages earnings through overseas business units that present greater information asymmetry. Similarly, Yoo et al. (2014) find that there is a positive relation between real earnings management and international diversification.

Lastly, multinational companies (hereafter, MNCs) are making capital investments or income transfers from countries with higher tax rates to those with lower tax rates. It was also reported that income transfers were made though transfer pricing among corporations carrying out large-scale internal transactions between subsidiaries (Grubert et al. 1993; Harris 1993; Klassen et al. 1993: Jacob 1996; Collins et al. 1998; Lo et al. 2010).

\subsubsection{Tax Avoidance Behavior}

The definition of 'tax avoidance behavior' differs according to the researcher. This study defines the term as all actions taken to lower the corporate tax burden. In this sense, tax avoidance behaviors include 'tax saving', which is the act of reducing the tax burden through the use of provisions on tax reduction and cuts stipulated in the tax law; 'tax avoidance', which refers to the technical reduction of the tax burden by taking actions not in compliance with the legislative purpose of the tax law based on the law's uncertainty or complexity, and 'tax evasion'; which is the act of reducing the tax burden through illegal behaviors, such as false reporting, income omission and overappropriation of expenses (Hanlon and Heitzman 2010; Ki 2012).

Previous studies related to tax avoidance behaviors are largely classified into two categories. The first category includes studies that determine which factors influence the tax avoidance behaviors of firms, whereas the second group of studies investigates how tax avoidance behaviors affect firm value. First, in relation to the determinants of tax avoidance behaviors, Kim and Jeong (2006) find that a firm's propensity to avoid tax increases with higher levels of total assets and pre-tax income and decreases with a higher debt ratio. Furthermore, Ko et al. (2007) posit that tax avoidance is positively related with the tax burden, profitability, and owner-controlled firms and negatively related with tax benefits. Meanwhile, according to previous studies, there is a negative relation between corporate social responsibility and tax avoidance. It means that diligently fulfilled their social responsibilities were less inclined to avoid tax (Watson 2011; Jeong Hong 2011; Ki 2012).

Desai and Dharmapala (2006) find that tax avoidance behaviors generated by the deputy problem between stockholders and management can be suppressed through stock options granted to the manager in a firm with a weak governance structure. Furthermore, Ko et al. (2007) posit that owner-controlled companies with high managerial ownership actively avoid tax. However, Jeong et al. (2011) find that that tax avoidance decreases with higher levels of managerial ownership. On the other hand, Park \& Hong Young (2009) find a negative relation between tax avoidance and the amount of shares held by foreigners, but Lee(2010) find the opposite results. 
Second, studies that observe the market response of tax avoidance include research conducted by Balakrishinan et al. (2010), Kim et al. (2011), Cheng et al. (2012), Lee \& Jeong (2008), Desai and Dharmapala (2009) and Ko et al. (2007). Balakrishinan et al. (2010) find that the complexity and unpredictability of corporate tax avoidance behaviors can worsen information asymmetry among market participants, such as credit rating agencies, finance analysts and investors. In other words, when the firm's propensity to avoid tax increases, it will increase the error and variance in earnings forecasts by finance analysts to worsen market information asymmetry. Kim et al. (2011) find a positive relation between corporate tax avoidance behaviors and stock price crash risk levels. On the other hand, Cheng et al. (2012) posit that corporate tax avoidance decreased among firms that actively invested in hedge funds. In other words, hedge funds will actively try to enhance firm value through the possession of undervalued companies, and this process will facilitate higher efficiency in tax laws for the relevant company to reduce its tax avoidance activities.

Lee \& Jeong (2008) find a negative relation between tax avoidance and stock prices if the firm's tax avoidance is publicly disclosed. On the other hand, there is a significantly positive stock response on disclosure day for firms that had completed tax payments faithfully. Meanwhile, there are some studies about the relation between corporate tax avoidance and firm value. Desai and Dharmapala (2009) cannot find any significant results between corporate tax avoidance and firm value. In contrast, Ko et al. (2007) find a positive relation between firm value and the estimated amount of tax avoided.

\subsection{Research Hypothesis}

FDI through overseas subsidiaries refers to a company's expansion into a new, less exploited market (Kogut 1983). Positive effects can be produced through FDI. For example, the losses generated in unprofitable markets can be offset by the revenue gained from others (Kogut 1985). In addition, market-appropriate investment decisions can lower risk while facilitating efficient management (Denis et al. 2002). Furthermore, the knowledge and experiences accrued in various markets can be used to enhance the value of tangible assets, such as manufacturing technology, marketing techniques and management ability, which will in turn bring about higher firm value (Hitt et al. 1997; Morck and Yeung 1998; Craig and Douglas 2000; Geringer et al. 2000). Companies that increase their levels of FDI can accumulate more management assets, knowledge and knowhow, all of which can be effectively adapted to the local business environment (Kogut and Zander 1993; Krugman 1991; Porter 1990).

In terms of tax law, firms that have expanded their business to various countries are more capable of actively using appropriate tax strategies that meet local circumstances. In other words, FDI through overseas subsidiaries provides a company with diverse ways to reduce their tax burden. For example, Article 104, Clause 15 of the Restriction of Special Taxation Act stipulates that overseas resource developers investing in foreign subsidiaries for the development of mineral resources must provide a tax credit for a certain amount of investment. Also, the law permits tax credits in case the foreign subsidiary has provided dividends to the MNC which possesses the overseas subsidiary (Corporate Tax Act, Article 57). In this sense, as there is a strong possibility that FDI through overseas subsidiaries will increase the tax avoidance of MNCs, we establish research hypothesis 1, as shown below.

Research hypothesis 1: The possession of an overseas subsidiary increases corporate tax avoidance.

Tax avoidance refers to the act in which a taxpayer performs aggressive tax planning to reduce their tax burden (Hanlon and Heitzman 2010; Ko et al. 2013). Aggressive tax planning is made possible due to different standards in tax law and accounting ${ }^{\mathrm{i}}$, in turn creating what is known as a BTD (book-tax difference). However, the BTD can be influenced by various factors, such as the accounting earnings management of the manager, tax deductions or tax credits, and the TP of the manager through overseas transactions.

In particular, to avoid tax, the company will typically reduce accounting income or increase expenditures. However, a company's ability to manage accounting income through sales or purchase transactions carried out with a business counterpart is limited. Therefore, it is typical to manage earnings using internal transactions made through the TP of a related party (Lo et al. 2010; Lee. 2010; Choi et al. 2011). For example, taxes can be avoided in related party transactions when the tax-burdened party raises the purchase price or the less-burdened party lowers the sales price. 
Meanwhile, MNCs are tempted to minimize taxation by arbitrarily determining transfer prices in transactions with overseas subsidiaries (Grubert and Mutti 1991; Harris et al. 1994; Grubert et al. 1994). For example, if the overseas subsidiary is based in a country which imposes high tax rates (or low tax rates), profits can be transferred to the parent company (or overseas subsidiary).

In this regard, the manager will make decisions in consideration of mutual tax costs. In particular, it is highly likely that the manager will use the transfer price in related party transactions to minimize the taxes incurred by the corporate group. Based on these predictions, we establish research hypothesis 2, as follows:

Research Hypothesis 2: MNCs that carry out more related party transactions through TP are more likely to avoid tax.

\section{RESEARCH DESIGN}

\subsection{Measurement of Tax Avoidance}

As an act carried out by a taxpayer to reduce the tax burden, 'tax avoidance' refers to the reduction of tax through legal measures unapproved by the tax law (Dyreng et al. 2008; Hanlon and Heitzman 2010). Thus, tax avoidance behaviors are typically based on the adjustment of the size of taxable income or on the use of various tax credits or tax reduction systems (Dyreng et al. 2008; Hanlon and Heitzman 2010). It is difficult to measure a firm's propensity to avoid tax due to the non-disclosure of tax affairs reports, and various studies are continuously being carried out to make up for such limitations (Manzon and Plesko 2002; Desai and Dharmapala 2006; Dyreng et al. 2008; Choi et al. 2011). This study uses the method newly presented by Desai and Dharmapala (2006) in addition to the GAAP ETR measure, the conventional measurement of tax avoidance.

\subsubsection{GAAP ETR}

First, the GAAP ETR is the amount calculated by dividing the income tax expense in the income statement by pretax income, as shown in Eq. (1) (Zimmerman 1983; Porcano 1986). This measurement value refers to the average level of the tax burden; it is advantageous in that it provides unlimited data and is easy to calculate.

$$
\text { GAAP ETR }_{\mathrm{t}}=\text { Income tax expense }_{\mathrm{t}} / \text { pretax }_{\text {income }}
$$

Although corporate tax avoidance is negatively related with the GAAP ETR, to facilitate an intuitive understanding of it and a comparison with other propensities, correlation analysis and regression analysis excluding descriptive statistics use TS (tax sheltering), which involves the multiplication of the GAAP ETR by (-1) to convert the correlation into a positive value.

$$
\mathrm{TS}_{\mathrm{t}}=(-1) \times \text { GAAP ETR }_{\mathrm{t}}
$$

\subsubsection{Book-Tax Difference}

Desai and Dharmapala (2006) posit that tax avoidance is included in a portion that is unexplainable by the manager's earnings management behavior as measured as the TA (total accruals) in the BTD (book-tax difference). Thus, Eq. (3) is used to measure corporate tax avoidance, whereas the residual of Eq. (3) becomes the measurement value of the second propensity for tax avoidance. 


$$
\mathrm{BTD}_{\mathrm{t}}=\alpha_{1} \mathrm{TA}_{\mathrm{t}}+\varepsilon_{\mathrm{t}}
$$

BTD $_{t}:\left(\right.$ Book Income $_{t}-$ Taxable Income $\left._{t}\right) /$ Total Asset $_{t-1}$

$\mathrm{TA}_{\mathrm{t}}:$ Total Accrual $_{\mathrm{t}}\left(=\mathrm{NI}_{\mathrm{t}}-\mathrm{OCF}_{\mathrm{t}}\right) /$ Total Asset $_{\mathrm{t}-1}$

$\varepsilon_{\mathrm{t}}\left(=\mathrm{TS} 2{ }_{\mathrm{t}}\right)$ : second measurement value of tax avoidance

As we mentioned earlier, tax avoidance is an act of aggressive tax planning to reduce the tax burden. Due to such characteristics, tax avoidance naturally creates BTDs (Manzon and Plesko 2002; Dyreng et al. 2008; Desai and Dharmapala 2006). In this sense, tax avoidance is closely related to the BTD. However, the BTD is influenced by accounting earnings management, tax avoidance through TP, and tax deductions or tax credits (Mills and Newberry 2001; Phillips et al. 2003; Berger 1993; Klassen et al. 2004).

Thus, it is very possible for the amount of tax avoided by the firm to be included in the part of the BTD that cannot be explained by the manager's earnings management behavior. Therefore, the amount of avoided tax can be measured only by removing from the BTD the effect of the earnings management behavior as measured by TA from among the BTD factors. This means of measuring the amount of avoided tax is advantageous in that it facilitates accurate measurements, as earnings management is a factor of the BTD (Joos et al. 2000; Philips 2003; Hanlon 2005). On the other hand, the effects of tax deductions and tax credits on the BTD partially control influential factors (e.g., the firm size, depreciation expense and company investments) during the empirical analysis through the inclusion of tax deductions and tax credits in the regression equation (Zimmerman 1983; Porcano 1986; Wang 1991; Stickney and McGee 1982).

TA is calculated by deducting operating cash flow from net income (Dechow et al. 1995). Meanwhile, the dependent variable of the BTD must be calculated to use Eq. (3). The BTD is calculated by deducting TI (taxable income) from the earning before tax. As the taxable income is confidential information, this study calculates the CTB (corporate tax burden) as noted in the financial statement by dividing it according to the firm's statutory tariff, as shown in Eq. (4) (Manzon and Plesko 2002).

$$
\mathrm{TI}_{\mathrm{t}}=\frac{\mathrm{CTBt}}{\gamma}
$$

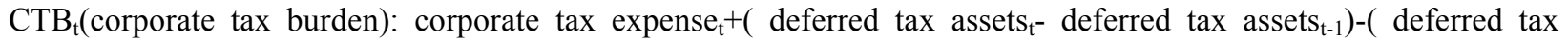
liabilities $\mathrm{t}^{-}$deferred tax liability $\left.\mathrm{t}_{\mathrm{t}-1}\right)$

$\gamma$ : statutory tariff

\subsection{Research Model}

We use Eq. (5) to analyze differences in tax avoidance behaviors between MNCs with overseas subsidiaries and other corporations.

$$
\begin{aligned}
& \text { TS1 2 } 2_{\mathrm{t}}=\alpha_{0}+\alpha_{1} \mathrm{SUB}_{\mathrm{t}}+\alpha_{2} \mathrm{RPT}_{\mathrm{t}}+\alpha_{3} \mathrm{SUB}_{\mathrm{t}} \times \mathrm{RPT}_{\mathrm{t}}+\alpha_{4} \mathrm{SIZE}_{\mathrm{t}}+\alpha_{5} \mathrm{LEV}_{\mathrm{t}}+\alpha_{6} \mathrm{ROA}_{\mathrm{t}}+\alpha_{7} \mathrm{PPE}_{\mathrm{t}}+\alpha_{8} \mathrm{OCF}_{\mathrm{t}} \\
& +\alpha_{9} \mathrm{FORN}_{\mathrm{t}}+\alpha_{10} \mathrm{INV}_{\mathrm{t}}+\alpha_{11} \mathrm{INTAN}_{\mathrm{t}}+\alpha_{12} \mathrm{MTB}_{\mathrm{t}}+\sum \mathrm{YEAR}+\sum \mathrm{IND}
\end{aligned}
$$

Where

$\mathrm{TS}_{\mathrm{t}}$ : tax avoidance behaviors measured by GAAP ETR 
$\mathrm{TS} 2_{\mathrm{t}}$ : tax avoidance behaviors measured by Desai and Dharmapala (2006)

$\mathrm{SUB}_{\mathrm{t}}: 1$ if a firm has overseas subsidiaries for year $\mathrm{t}$, and 0 otherwise;

$\mathrm{RPT}_{\mathrm{t}}$ : total transactions to the related-party sales scaled by total sales ;

$\mathrm{SIZE}_{\mathrm{t}}: \log$ of total assets;

$\mathrm{LEV}_{\mathrm{t}}$ : debt-assets ratio;

$\mathrm{ROA}_{\mathrm{t}}$ : return-on-assets, net income scaled by average total assets ;

$\mathrm{PPE}_{\mathrm{t}}$ : property, plant and equipment scaled by average total assets ;

FORN $_{\mathrm{t}}$ : the percentage of common shares held by foreign investors;

$\mathrm{INV}_{\mathrm{t}}$ : acquisition of machinery and equipment scaled by average total assets;

INTAN ${ }_{\mathrm{t}}$ : intangible asset scaled by average total assets;

$\mathrm{MTB}_{\mathrm{t}}$ : market-to-book ratio

$\sum$ YEAR: year dummy

$\sum$ IND: industry dummy

We use Eq. (5) to examine Hypothesis 1 and Hypothesis 2. For the dependent variable, the propensity of the manager to avoid tax, this study uses the method presented by Desai and Dharmapala (2006) along with the GAAP ETR. SUB, the main interest variable of this study, verifies whether the firm is an MNC. Thus, companies with overseas subsidiaries are given a value of 1 and those without a subsidiary will be scored with a 0 . If a company with an overseas subsidiary shows a higher propensity to avoid tax than a firm without a subsidiary, $\alpha_{1}$ will hold a significantly positive number.

Furthermore, the possibility of tax avoidance increases in cases of internal transactions through related-party TP, as mentioned in research hypothesis 1 . Related to this, it is predicted that $\alpha_{2}$ will hold a significantly positive number if the increase in internal transactions through related-party TP enhances the domestic firm's propensity to avoid tax. On the other hand, as mentioned in research hypothesis $2, \alpha_{3}$ will also present a significantly positive number if a higher propensity to avoid tax is shown among MNCs that have made many transactions through related-party TP.

On the other hand, Eq. (5) controlled variables that can influence corporate tax avoidance. First, we control the firm size (SIZE), leverage ratio (LEV) and the return on assets ratio (ROA) as variables related to company characteristics. Large companies can establish superior taxation strategies due to economies of scale while also facing a greater risk of being exposed to various regulations, it raises the 'political cost hypothesis', which states that large firms are more inclined to prefer tax smoothing rather than aggressive tax avoidance strategies (Zimmerman 1983; Porcano 1986; Wang 1991). As for the ROA, a variable related to corporate performance, lucrative firms are expected to be more aggressive in avoiding tax to reduce tax-related cash outflow (Ayers et al. 2009; Atwood et al. 2010). On the other hand, as the tax reduction effects that can be gained through debt use require additional interest costs, it is likely that firms will show a rather passive attitude toward tax avoidance, which is a non-debt tax reduction method (Graham and Tucker 2006; Wilson 2009).

As companies with a high ratio of depreciable operating assets (PPE) can use various means to lower their tax burden, firms without spare funds (OCF) will attempt to reduce corporate tax spending and will thus be more inclined to avoid tax aggressively (Stickney and McGee 1982; Foley et al. 2007). Furthermore, foreign investors are more likely to show interest in book income than in taxable income. In this sense, companies with a high foreign 
investor rate (FORN) are likely to be more passive in avoiding tax due to the minimal incentive to reduce taxable income. This implies that foreign investors actively influence managers to make decisions that maximize their profits, such as the provision of high dividends through the maximization of book income rather than the minimization of the tax burden through tax avoidance strategies (Park \& Hong 2009; Ki 2012; Jeon \& Park 2014).

As the tax law in Korea provides special taxation provisions for technology and manpower development, corporate investment (INV) was included as a control variable. Thus, a higher level of investment is expected to lower taxes significantly, as it leads to the provision of various tax credits (Berger 1993; Klassen et al. 2004). Intangible assets (INTAN) will be positively related with tax avoidance, as they can be used as a means to transfer income and due to possible differences between accounting and taxable depreciation methods (Chen et al. 2010). As companies with high future growth potential (MTB) show a weak propensity to avoid tax in general, a negative relation can be expected (Chen et al. 2010; Robinson et al. 2010). Lastly, a year dummy and a industry dummy were added to control for year and industry effects.

\subsection{Sample Selection}

Among the companies listed on the Korea Exchange from 2001 to 2010, study samples were restricted to firms that meet the following conditions.

(1) Firms that make settlements on December 31

(2) Firms unaffiliated with the finance industry, such as banking, investment banking, securities or insurance

(3) Firms possessing information required for empirical analyses

(4) Firms with financial variables that remain in the annual top/bottom $1 \%$ percentile

Thus, to increase sample homogeneity, samples were restricted to companies that make settlements in December, and finance-related firms were excluded. The reason for these exclusions stems from differences between financial firms and manufacturing or product sales companies in terms of the management environment, strategies and accounting management methods used. Furthermore, financial firms largely differed in terms of their financial structure from general manufacturers. On the other hand, to minimize the effect of extreme values, companies with financial variables deviating from the top/bottom $1 \%$ were also excluded. Table 1 summarizes the sample selection procedure.

Table 1. Sample selection

\begin{tabular}{l|c}
\hline \multicolumn{1}{c|}{ Sample selection criteria } & Firm-years \\
\hline $\begin{array}{l}\text { Initial sample traded in Korea Exchange for 2001-2010 with December fiscal years } \\
\text { and in non-banking industries. }\end{array}$ & 6,740 \\
\hline (-) Observations for which selected financial data are not available & $(1,919)$ \\
\hline (-) Observations that selected financial data lie outside top or bottom one percentiles & $(236)$ \\
\hline - Final sample & 4,585 \\
\hline
\end{tabular}

\section{RESULTS OF THE EMPIRICAL ANALYSIS}

\subsection{Descriptive Statistics and Correlation Analysis}

Table 2 presents the descriptive statistics of the main variables used in this study. The mean value (median) of the GAAP ETR is $0.209(0.242)$. The mean value (median) of TS2 is $0.012(0.011)$, and the mean (median) value of TS3 is $0.009(0.005)$.

The mean value of SUB, the major interest variable in this study, is 0.049 , showing that nearly $5 \%$ of sample firms own overseas subsidiaries. The mean value of RPT (related party transactions) is 0.025 . On the other hand, the mean values of LEV and ROA is 0.453 and 0.072 , respectively, implying that many lucrative firms with outstanding capital structures are included in the study sample. The mean value (median) of FORN is 10.422 (2.800), thus showing a large difference between the mean and the median. This appears to have resulted because foreign investment is generally weighted toward a few large corporations. 
Table 2. Descriptive Statistics of Selected Variables

\begin{tabular}{l|c|c|c|c|r|r|r}
\hline \multicolumn{1}{c|}{ Variables } & Mean & Std.Dev. & $\mathbf{1 \%}$ & $\mathbf{2 5 \%}$ & Median & $\mathbf{7 5 \%}$ & $\mathbf{9 9 \%}$ \\
\hline$G A A P E T R_{\mathrm{t}}$ & 0.209 & 0.190 & -0.506 & 0.155 & 0.242 & 0.293 & 0.631 \\
\hline$T S 2_{\mathrm{t}}$ & 0.012 & 0.041 & -0.089 & -0.011 & 0.011 & 0.033 & 0.130 \\
\hline$T S 3_{\mathrm{t}}$ & 0.009 & 0.025 & -0.048 & -0.003 & 0.005 & 0.016 & 0.104 \\
\hline$S U B_{\mathrm{t}}$ & 0.049 & 0.216 & 0.000 & 0.000 & 0.000 & 0.000 & 1.000 \\
\hline$R P T_{\mathrm{t}}$ & 0.025 & 0.136 & 0.000 & 0.002 & 0.012 & 0.031 & 0.118 \\
\hline$S I Z E_{\mathrm{t}}$ & 26.447 & 1.483 & 23.877 & 25.403 & 26.169 & 27.238 & 30.707 \\
\hline$L E V_{\mathrm{t}}$ & 0.453 & 0.202 & 0.072 & 0.305 & 0.454 & 0.593 & 0.911 \\
\hline$R O A_{\mathrm{t}}$ & 0.072 & 0.354 & 0.002 & 0.028 & 0.053 & 0.090 & 0.267 \\
\hline$P P E_{\mathrm{t}}$ & 0.206 & 0.142 & 0.003 & 0.104 & 0.178 & 0.277 & 0.641 \\
\hline$O C F_{\mathrm{t}}$ & 0.073 & 0.092 & -0.124 & 0.022 & 0.066 & 0.118 & 0.342 \\
\hline$F O R N_{\mathrm{t}}$ & 10.422 & 15.405 & 0.000 & 0.090 & 2.800 & 14.940 & 64.390 \\
\hline$I N V_{\mathrm{t}}$ & 0.006 & 0.014 & 0.000 & 0.000 & 0.002 & 0.007 & 0.071 \\
\hline$I N T A N_{\mathrm{t}}$ & 0.010 & 0.030 & -0.030 & 0.000 & 0.002 & 0.009 & 0.126 \\
\hline$M T B_{\mathrm{t}}$ & 1.032 & 1.161 & 0.139 & 0.434 & 0.712 & 1.206 & 5.562 \\
\hline
\end{tabular}

Table 2 presents the descriptive statistics of the main variables used in this study. The sample consists of 4,585 nonfinancial firm-years that are traded over Korean Stock Exchange for 2001-2010 with non-missing data collected from KIS-Value and database. GAAP ETR $\mathrm{t}_{\mathrm{t}}$ is income tax at the end of year $t$ divided pretax income. $\mathrm{TS}_{\mathrm{t}}$ is tax avoidance calculated as the absolute value of the residual estimated from the cross-sectional Desai and Dharmapala's (2006) model: $\mathrm{BTD}_{t}=\alpha_{1} \mathrm{TA}_{t}+\mathrm{e}_{\mathrm{t}}$ where $\mathrm{BTD}_{\mathrm{t}}$ is book-tax differences, and $\mathrm{TA}_{t}$ is total accruals. $\mathrm{TS}_{\mathrm{t}}$ is tax avoidance calculated as tax subsidy on equity. $\mathrm{SUB}_{\mathrm{t}}$ is a dummy variable that equals 1 if a firm has overseas subsidiaries, and 0 otherwise. $\mathrm{RPT}_{t}$ is total transactions to the related-party sales scaled by total sales. $\mathrm{SIZE}_{\mathrm{t}}$ is $\log$ of total assets. $\mathrm{LEV}_{\mathrm{t}}$ is debt-assets. $\mathrm{ROA}_{\mathrm{t}}$ is return-on-assets, net income scaled by average total assets. $\mathrm{PPE}_{\mathrm{t}}$ is property, plant and equipment scaled by average total assets. $\mathrm{FORN}_{\mathrm{t}}$ is the percentage of common shares held by foreign investors. $\mathrm{INV}_{\mathrm{t}}$ is acquisition of machinery and equipment scaled by average total assets. INTAN $\mathrm{N}_{t}$ is intangible asset scaled by average total assets. $\mathrm{MTB}_{\mathrm{t}}$ is market-to-book ratio.

Table 3 presents the correlations between the main variables. When observing the correlations between variables showing tax avoidance, it becomes clear that tax avoidance as measured through the GAAP ETR $\left(T S 1_{t}\right)$ and tax avoidance as measured through the method given by Desai and Dharmapala (2006) $\left(\mathrm{TS} 2_{\mathrm{t}}\right.$ ) have strong positive correlation at 0.255 at the $1 \%$ significance level. The correlation between tax avoidance as measured through the GAAP ETR $\left(\mathrm{TS}_{\mathrm{t}}\right.$ ) and tax avoidance as measured through tax subsidies on equity (TS3) is significantly positive at 0.076 at the $1 \%$ significance level. Furthermore, tax avoidance measured through the method given by Desai and Dharmapala (2006) $\left(\mathrm{TS}_{\mathrm{t}}\right.$ ) has a statistically significant positive correlation of 0.060 with tax avoidance measured through tax subsidies on equity $\left(\mathrm{TS}_{\mathrm{t}}\right)$. Thus, correlations between measurements showing tax avoidance are significantly positive in general.

Meanwhile, tax avoidance generally presents a positive correlation with $\mathrm{ROA}_{t}, \mathrm{PPE}_{t}, \mathrm{INV}_{\mathrm{t}}$ and $\mathrm{INTAN}_{\mathrm{t}}$, but it is negatively related with $\mathrm{FORN}_{\mathrm{t}}$ and $\mathrm{OCF}_{\mathrm{t}}$. 
Table 3. Pearson Correlations

\begin{tabular}{c|c|c|c|c|c|c|c|c|c|c|c|c|c}
\hline Variable & $\mathbf{T S 2}_{\mathbf{t}}$ & $\mathbf{T S 3}_{\mathbf{t}}$ & $\mathbf{S U B}_{\mathbf{t}}$ & $\mathbf{R P T}_{\mathbf{t}}$ & $\mathbf{S I Z E}_{\mathbf{t}}$ & $\mathbf{L E V}_{\mathbf{t}}$ & $\mathbf{R O A}_{\mathbf{t}}$ & $\mathbf{P P E}_{\mathbf{t}}$ & $\mathbf{O C F}_{\mathbf{t}}$ & $\mathbf{F O R N}_{\mathbf{t}}$ & $\mathbf{I N V}_{\mathbf{t}}$ & $\mathbf{I N T A N}_{\mathbf{t}}$ & $\mathbf{M T B}_{\mathbf{t}}$ \\
\hline$T S 1_{\mathrm{t}}$ & 0.255 & 0.076 & -0.037 & 0.022 & -0.044 & 0.023 & 0.025 & 0.057 & -0.047 & -0.076 & 0.064 & 0.007 & 0.004 \\
\hline$T S 2_{\mathrm{t}}$ & & 0.060 & 0.014 & 0.001 & 0.084 & 0.123 & 0.038 & 0.248 & 0.670 & 0.030 & 0.075 & 0.086 & 0.109 \\
\hline$T S 3_{\mathrm{t}}$ & & & -0.011 & -0.004 & 0.081 & 0.059 & 0.190 & 0.025 & 0.029 & -0.024 & 0.008 & -0.035 & 0.041 \\
\hline$S U B_{\mathrm{t}}$ & & & & 0.001 & 0.187 & 0.109 & -0.012 & -0.102 & -0.037 & 0.089 & -0.033 & -0.018 & 0.012 \\
\hline$R P T_{\mathrm{t}}$ & & & & & 0.074 & -0.001 & -0.002 & 0.034 & -0.009 & 0.048 & -0.003 & -0.004 & 0.004 \\
\hline$S I Z E_{\mathrm{t}}$ & & & & & & 0.177 & -0.048 & 0.173 & 0.074 & 0.478 & -0.162 & 0.040 & 0.149 \\
\hline$L E V_{\mathrm{t}}$ & & & & & & & -0.007 & 0.228 & -0.062 & -0.115 & -0.023 & 0.097 & 0.111 \\
\hline$R O A_{\mathrm{t}}$ & & & & & & & & -0.032 & -0.259 & 0.019 & 0.048 & -0.005 & 0.335 \\
\hline$P P E_{\mathrm{t}}$ & & & & & & & & & 0.200 & 0.025 & 0.124 & 0.026 & -0.031 \\
\hline$O C F_{\mathrm{t}}$ & & & & & & & & & & 0.176 & 0.121 & 0.084 & 0.162 \\
\hline$F O R N_{\mathrm{t}}$ & & & & & & & & & & & -0.039 & 0.027 & 0.284 \\
\hline$I N V_{\mathrm{t}}$ & & & & & & & & & & & & 0.064 & 0.078 \\
\hline$I N T N_{\mathrm{t}}$ & & & & & & & & & & & & \\
\hline
\end{tabular}

Table 3 presents the correlations between the main variables. TS1 $1_{t}$ is tax avoidance which multiplies (-) with the GAAP ETR. TS2 ${ }_{t}$ is tax avoidance calculated as the absolute value of the residual estimated from the cross-sectional Desai and Dharmapala's (2006) model: $\mathrm{BTD}_{t}=\alpha_{1} \mathrm{TA}_{t}+\mathrm{e}_{\mathrm{t}}$ where $\mathrm{BTD}_{\mathrm{t}}$ is book-tax differences, and $\mathrm{TA}_{\mathrm{t}}$ is total accruals. $\mathrm{TS}_{\mathrm{t}}$ is tax avoidance calculated as tax subsidy on equity for year $\mathrm{t}$. $\mathrm{SUB}_{\mathrm{t}}$ is a dummy variable that equals 1 if a firm has overseas subsidiaries, and 0 otherwise. $\mathrm{RPT}_{\mathrm{t}}$ is total transactions to the related-party sales scaled by total sales. SIZE $\mathrm{t}$ is $\log$ of total assets. $\mathrm{LEV}_{\mathrm{t}}$ is debt-assets. $\mathrm{ROA}_{\mathrm{t}}$ is return-on-assets, net income scaled by average total assets. $\mathrm{PPE}_{\mathrm{t}}$ is property, plant and equipment scaled by average total assets. $\mathrm{FORN}_{\mathrm{t}}$ is the percentage of common shares held by foreign investors. $\mathrm{INV}_{\mathrm{t}}$ is acquisition of machinery and equipment scaled by average total assets. INTAN $\mathrm{I}_{\mathrm{t}}$ is intangible asset scaled by average total assets. $\mathrm{MTB}_{\mathrm{t}}$ is market-to-book ratio. The sample consists of 4,585 non-financial firm-years that are traded over Korean Stock Exchange for 2001-2010 with non-missing data collected from KIS-Value and database. Two-tailed t-test, coefficients in bolds and italics are significant at less than $1 \%$ level.

\subsection{Correlation Between MNCs and Tax Avoidance}

\subsubsection{Use of the GAAP ETR as a Measurement of Tax Avoidance}

Table 4 presents the results of hypotheses 1 and 2 . The GAAP ETR $\left(\mathrm{TS} 1_{\mathrm{t}}\right)^{\mathrm{ii}}$ was used as the dependent variable. Our main interest variables are $\left(\mathrm{SUB}_{\mathrm{t}}\right)$ and $\left(\mathrm{RPT}_{\mathrm{t}}\right)$ and we control the financial variables that can influence corporate tax avoidance.

First, the result of the verification of hypothesis $1\left(\alpha_{1}\right)$ shows that there is no relation between MNCs and tax avoidance. The absence of a relation between the two variables may have arisen due to the following reasons. Tax avoidance is a taxation strategy for reducing the tax burden by applying tax laws to the taxpayer's advantage through the use of differences between tax laws and accounting. Due to such characteristics, tax avoidance naturally creates BTDs (Manzon and Plesko 2002; Dyreng et al. 2008; Desai and Dharmapala 2006). In this sense, tax avoidance is closely related to BTDs. However, BTDs are influenced by earnings management, tax avoidance through TP, and tax deductions or tax credits (Mills and Newberry 2001; Phillips et al. 2003; Berger 1993; Klassen et al. 2004). On the other hand, as the GAAP ETR merely shows the corporate tax burden without capturing the fundamentals of corporate tax avoidance, it may not have the ability to distinguish a firm's propensity to avoid tax (Wilkie and Limberg 1993; Dyreng et al. 2008).

Next, when observing the second and third columns, it becomes clear that there is a significantly positive relation between RPT and corporate tax avoidance as measured through the GAAP ETR (TS1 $1_{t}$ ). The coefficient of RPT is 0.031 and significantly positive at the $5 \%$ level. Therefore, it was shown that companies minimized their tax burden through arbitrary decisions about the transfer price in RPT.

On the other hand, $\alpha_{3}$ in the last column presents the results on the verification of research hypothesis 2 . The coefficient of $\mathrm{SUB}_{\mathrm{t}} * \mathrm{RPT}_{\mathrm{t}}$ is 0.048 and significantly negative at $1 \%$ level. It means that among MNCs with overseas subsidiaries, those that carried out many foreign RPTs showed a higher propensity to avoid tax. 
To summarize the results of Table 4 below, there appeared to be no relation between MNCs and corporate tax avoidance, but MNCs carrying out many foreign RPTs appeared to avoid tax aggressively by using TP.

Table 4. The Regression Analysis of Tax Avoidance Using TS1

\begin{tabular}{|c|c|c|c|c|c|c|c|}
\hline Variables & Exp. Sign & Coeffs & $(t-s t a t)^{a}$ & Coeffs & $(t-s t a t)^{a}$ & Coeffs & $(t-s t a t)^{a}$ \\
\hline Intercept & $+/-$ & -0.139 & $(-2.05)^{*}$ & -0.109 & $(-1.65)$ & -0.122 & $(-1.93)^{*}$ \\
\hline$S U B_{\mathrm{t}}$ & + & -0.018 & $(-1.58)$ & & & -0.040 & $(-1.14)$ \\
\hline$R P T_{\mathrm{t}}$ & + & & & 0.031 & $(2.11)^{* *}$ & 0.028 & $(1.88)^{*}$ \\
\hline$S U B_{\mathrm{t}} * R P T_{\mathrm{t}}$ & + & & & & & 0.046 & $(1.76)^{*}$ \\
\hline$S I Z E_{\mathrm{t}}$ & $+/-$ & -0.004 & $(-1.3)$ & -0.006 & $(-2.1)^{* *}$ & -0.005 & $(-1.96)^{*}$ \\
\hline$L E V_{\mathrm{t}}$ & - & 0.007 & $(0.28)$ & 0.005 & $(0.21)$ & 0.009 & $(0.36)$ \\
\hline$R O A_{\mathrm{t}}$ & + & 0.528 & $(4.86)^{* * *}$ & 0.530 & $(4.71)^{* * *}$ & 0.527 & $(4.68)^{* * *}$ \\
\hline$P P E_{\mathrm{t}}$ & + & 0.105 & $(2.91)^{* *}$ & 0.114 & $(3.24)^{* * *}$ & 0.108 & $(2.96)^{* * *}$ \\
\hline$O C F_{\mathrm{t}}$ & - & -0.258 & $(-5.7)^{* * *}$ & -0.259 & $(-5.87)^{* * *}$ & -0.259 & $(-5.83)^{* * *}$ \\
\hline$F O R N_{\mathrm{t}}$ & - & -0.001 & $(-4.5)^{* * *}$ & -0.001 & $(-4.44)^{* * *}$ & -0.001 & $(-4.34)^{* * *}$ \\
\hline$I N V_{\mathrm{t}}$ & + & 0.718 & $(3.9)^{* * *}$ & 0.700 & $(4.02)^{* * *}$ & 0.714 & $(4.02)^{* * *}$ \\
\hline$I N T A N_{\mathrm{t}}$ & + & -0.057 & $(-0.47)$ & -0.062 & $(-0.5)$ & -0.067 & $(-0.54)$ \\
\hline$M T B_{\mathrm{t}}$ & - & 0.006 & $(0.88)$ & 0.007 & $(0.95)$ & 0.007 & $(0.94)$ \\
\hline \multicolumn{2}{|l|}{$\sum Y E A R$} & \multicolumn{2}{|c|}{ Included } & \multicolumn{2}{|c|}{ Included } & \multicolumn{2}{|c|}{ Included } \\
\hline$\sum I N D$ & & \multicolumn{2}{|c|}{ Included } & \multicolumn{2}{|c|}{ Included } & \multicolumn{2}{|c|}{ Included } \\
\hline Adj. $R^{2}$ & & \multicolumn{2}{|c|}{0.191} & \multicolumn{2}{|c|}{0.190} & \multicolumn{2}{|c|}{0.191} \\
\hline
\end{tabular}

Table 4 presents the results of hypotheses 1 and 2 . The dependent variable is $\mathrm{TS}_{\mathrm{t}}$. TS1 $1_{\mathrm{t}}$ is tax avoidance which multiplies(-) with the GAAP ETR. SUB ${ }_{t}$ is a dummy variable that equals 1 if a firm has overseas subsidiaries, and 0 otherwise. RPT $T_{t}$ is total transactions to the related-party sales scaled by total sales. SIZE $E_{t}$ is log of total assets. LEV $_{t}$ is debt-assets. $\mathrm{ROA}_{t}$ is return-on-assets, net income scaled by average total assets. $\mathrm{PPE}_{\mathrm{t}}$ is property, plant and equipment scaled by average total assets. FORN $N_{t}$ is the percentage of common shares held by foreign investors. INV is acquisition of machinery and equipment scaled by average total assets. INTAN $\mathrm{N}_{t}$ is intangible asset scaled by average total assets. $\mathrm{MTB}_{\mathrm{t}}$ is market-to-book ratio. The sample consists of 4,585 non-financial firm-years that are traded over Korean Stock Exchange for 2001-2010 with non-missing data collected from KIS-Value database. ${ }^{a *}$, **, *** is two-tailed t-test with t-statistics adjusted for clustering of standard errors by firm and year, significant at less than $10 \%, 5 \%$, and $1 \%$ levels, respectively.

When observing the other control variables that can influence corporate tax avoidance, $\mathrm{SIZE}_{\mathrm{t}}$ presents a statistically significantly negative relation with TS1. These results imply that large corporations show a more passive stance in terms of tax avoidance, as they prefer tax smoothing, as stated in the political cost hypothesis (Zimmerman 1983; Porcano 1986; Wang 1991). As predicted, $\mathrm{ROA}_{\mathrm{t}}, \mathrm{PPE}_{\mathrm{t}}$ and $\mathrm{INV}_{\mathrm{t}}$ are positively related with corporate tax avoidance.

A higher foreigner investment ratio was negatively related with corporate tax avoidance. This implies that foreign investors who invest in Korea show a relatively passive attitude regarding tax avoidance, as they prefer high dividends and value profitability indicators (Park \& Hong 2009). As predicted, there is significantly negative relation between operating cash flow and TS1, corresponds to the expectation that firms with insufficient liquidity will be more aggressive in their efforts to avoid taxes (Foley et al. 2007).

\subsubsection{Use of the Method Presented by Desai and Dharmapala (2006) as a Measurement of Tax Avoidance}

Table 5 presents the regression results that measures tax avoidance using the method presented by Desai and Dharmapala (2006). TS2 presented by Desai and Dharmapala (2006), the measurement of tax avoidance, is a dependent variable. Our main interest variables are $\mathrm{SUB}_{\mathrm{t}}$ and $\mathrm{RPT}_{\mathrm{t}}$. We also control the financial variables that can influence corporate tax avoidance.

First, the results of the verification of hypothesis 1 show that tax avoidance increases among MNCs with overseas subsidiaries and related parties transactions. Thus, there are a significantly positive relation between TS2(the measurement of tax avoidance) and $\mathrm{SUB}_{\mathrm{t}}$. Furthermore, the coefficient of RPT is 0.04 and significantly positive at the $5 \%$ level. 
Column 3 represents the result of hypothesis 2 . The coefficient of $\mathrm{SUB}_{t}{ }^{*} \mathrm{RPT}_{\mathrm{t}}$ is 0.017 and significantly positive at the 5\% level. It means that among MNCs with overseas subsidiaries, those that carried out many foreign RPTs showed a higher propensity to avoid tax.

To summarize the results of Table 5, a significantly positive relation was shown between MNCs and the manager's propensity to avoid tax, thus implying that managers of MNCs avoided tax through related-party TP. In this sense, tax avoidance was more common among MNCs with overseas subsidiaries, and the propensity to avoid tax increased among firms that carried out more internal transactions through related-party TP. It means that companies actively pursued tax avoidance strategies for reducing their tax burden through both FDI and internal transactions through TP between overseas subsidiaries.

On the other hand, when observing the other control variables that can influence corporate tax avoidance, $\mathrm{ROA}_{t}$ and $\mathrm{PPE}_{\mathrm{t}}$ are in general positively related with tax avoidance, as predicted. However, contrary to our expectations, $\mathrm{TS} 2_{\mathrm{t}}$ is significantly positive relations with $\mathrm{OCF}_{\mathrm{t}}$ and $\mathrm{LEV}_{\mathrm{t}}$, a finding similar to the results in earlier studies (Park \& Hong 2009; Choi et al. 2011: Jeon 2013).

Table 5. The Regression Analysis of Tax Avoidance Using TS2

\begin{tabular}{|c|c|c|c|c|c|c|c|}
\hline Variables & Exp. Sign & Coeffs & $(t-s t a t)^{a}$ & Coeffs & $(t-s t a t)^{a}$ & Coeffs & ${\text { (t-stat })^{a}}$ \\
\hline Intercept & $+/-$ & -0.015 & $(-1.06)$ & -0.016 & $(-1.18)$ & -0.012 & $(-0.83)$ \\
\hline$S U B_{\mathrm{t}}$ & + & 0.004 & $(3.31)^{* * *}$ & & & 0.004 & $(2.73)^{* *}$ \\
\hline$R P T_{\mathrm{t}}$ & + & & & 0.004 & $(2.77)^{* *}$ & 0.004 & $(2.32)^{* *}$ \\
\hline$S U B_{\mathrm{t}} * R P T_{\mathrm{t}}$ & + & & & & & 0.017 & $(2.36)^{* *}$ \\
\hline$S I Z E_{\mathrm{t}}$ & $+/-$ & 0.000 & $(-0.03)$ & 0.000 & $(-0.07)$ & 0.000 & $(-0.3)$ \\
\hline$L E V_{\mathrm{t}}$ & - & 0.028 & $(3.92)^{* * *}$ & 0.028 & $(3.97)^{* * *}$ & 0.028 & $(3.94)^{* * *}$ \\
\hline$R O A_{\mathrm{t}}$ & + & 0.222 & $(5.54)^{* * *}$ & 0.223 & $(5.54)^{* * *}$ & 0.222 & $(5.52)^{* * *}$ \\
\hline$P P E_{\mathrm{t}}$ & + & 0.013 & $(3.04)^{* * *}$ & 0.012 & $(2.96)^{* *}$ & 0.014 & $(3.08)^{* * *}$ \\
\hline$O C F_{\mathrm{t}}$ & - & 0.423 & $(35.64)^{* * *}$ & 0.423 & $(35.88)^{* * *}$ & 0.423 & $(35.44)^{* * *}$ \\
\hline$F O R N_{\mathrm{t}}$ & - & -0.000 & $(-7.01)^{* * *}$ & -0.000 & $(-6.84)^{* * *}$ & -0.000 & $(-6.87)^{* * *}$ \\
\hline$I N V_{\mathrm{t}}$ & + & -0.057 & $(-1.26)$ & -0.055 & $(-1.25)$ & -0.057 & $(-1.27)$ \\
\hline$I N T A N_{\mathrm{t}}$ & + & 0.017 & $(0.51)$ & 0.014 & $(0.44)$ & 0.015 & $(0.45)$ \\
\hline$M T B_{\mathrm{t}}$ & - & 0.001 & $(0.46)$ & 0.001 & $(0.47)$ & 0.001 & $(0.52)$ \\
\hline SYEAR & & \multicolumn{2}{|c|}{ Included } & \multicolumn{2}{|c|}{ Included } & \multicolumn{2}{|c|}{ Included } \\
\hline$\sum I N D$ & & \multicolumn{2}{|c|}{ Included } & \multicolumn{2}{|c|}{ Included } & \multicolumn{2}{|c|}{ Included } \\
\hline $\operatorname{Adj} . R^{2}$ & & \multicolumn{2}{|c|}{0.586} & \multicolumn{2}{|c|}{0.636} & \multicolumn{2}{|c|}{0.588} \\
\hline
\end{tabular}

Table 5 presents the regression results that measures tax avoidance using the method presented by Desai and Dharmapala (2006). TS2 presented by Desai and Dharmapala (2006), the measurement of tax avoidance, was used as the dependent variable. TS2 $2_{t}$ is tax avoidance calculated as the absolute value of the residual estimated from the cross-sectional Desai and Dharmapala's (2006) model: $\mathrm{BTD}_{t}=\alpha_{1} \mathrm{TA}_{t}+\mathrm{e}_{\mathrm{t}}$ where $\mathrm{BTD}_{\mathrm{t}}$ is book-tax differences, and $\mathrm{TA}_{\mathrm{t}}$ is total accruals. $\mathrm{SUB}_{\mathrm{t}}$ is a dummy variable that equals 1 if a firm has overseas subsidiaries, and 0 otherwise. $\mathrm{RPT}_{\mathrm{t}}$ is total transactions to the related-party sales scaled by total sales. SIZE $\mathrm{t}_{\mathrm{t}}$ is $\log$ of total assets. $\mathrm{LEV}_{\mathrm{t}}$ is debtassets. $\mathrm{ROA}_{t}$ is return-on-assets, net income scaled by average total assets. $\mathrm{PPE}_{t}$ is property, plant and equipment scaled by average total assets. FORN $\mathrm{t}_{\mathrm{t}}$ is the percentage of common shares held by foreign investors. $\mathrm{INV}_{\mathrm{t}}$ is acquisition of machinery and equipment scaled by average total assets. INTAN $\mathrm{N}_{\mathrm{t}}$ is intangible asset scaled by average total assets. $\mathrm{MTB}_{\mathrm{t}}$ is market-to-book ratio. The sample consists of 4,585 non-financial firm-years that are traded over Korean Stock Exchange for 2001-2010 with non-missing data collected from KIS-Value database. ${ }^{{ }^{*}, * *},{ }^{* * *}$ is two-tailed t-test with t-statistics adjusted for clustering of standard errors by firm and year, significant at less than $10 \%, 5 \%$, and $1 \%$ levels, respectively.

To summarize Tables 4 and 5, corporate tax avoidance increased in firms that carried out many internal transactions through related-party TP, and MNCs pursued aggressive tax avoidance strategies to reduce their tax burdens by carrying out internal transactions through overseas related-party TP. However, there are mixed results between corporate tax avoidance and the possession of overseas subsidiaries. In other words, significant relations are not found when the GAAP ETR $\left(\mathrm{TS}_{\mathrm{t}}\right.$ ) was used as the measurement of tax avoidance, but there is a positive relation between corporate tax avoidance and the possession of overseas subsidiaries during the use of the tax avoidance as 
measured by Desai and Dharmapala (2006) $\left(\mathrm{TS}_{\mathrm{t}}\right)$. In this sense, as the results of hypothesis 1 differ according to the measurement of corporate tax avoidance, we conduct a robustness analysis using a different measurement of tax avoidance.

\section{ROBUSTNESS ANALYSIS}

This chapter verifies hypotheses 1 and 2 with different measurements of corporate tax avoidance. Tax avoidance as measured by the GAAP ETR failed to reflect the fundamental traits of tax avoidance. Tax avoidance naturally creates BTDs, which are in turn influenced by earnings management, tax avoidance through TP, and tax deductions or tax credits (Mills and Newberry 2001; Phillips et al. 2003; Berger 1993; Klassen et al. 2004). Thus, it is highly likely that a manager's tax avoidance behavior is included in the portion that is unexplainable by the manager's earnings management behavior carried out for accounting purposes with regard to the BTD. However, as the GAAP ETR merely shows the corporate tax burden without capturing the fundamentals of corporate tax avoidance, it may lack the ability to distinguish a firm's propensity to avoid tax (Wilkie and Limberg 1993; Dyreng et al. 2008).

In this sense, TSE (tax subsidy on equity), which facilitates a more direct measurement of corporate tax benefits, may be a more appropriate measure of corporate tax avoidance in terms of availability or credibility (Wilkie and Limberg 1993; Park \& Hong 2009). Therefore, TSE is used as a complementary measure of corporate tax avoidance, as it meets the definition of tax avoidance specified in this study, which explicitly states that tax benefits also result in the reduction of taxes. Thus, the third measurement of tax avoidance TSE (TS3 $\mathrm{t}_{\mathrm{t}}$ ) is measured by Eq. (6).

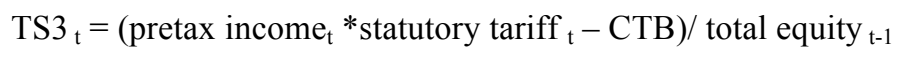

Where;

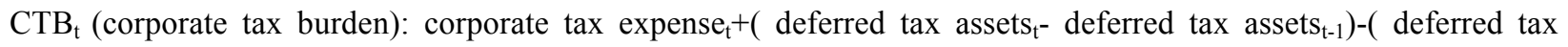
liabilities $\mathrm{t}^{-}$deferred tax liability $\left.\mathrm{t}_{\mathrm{t}-1}\right)$

Table 6 reports the results of hypothesis 1 and 2 . TS3 $3_{t}$ measured through TSE, the complementary measurement of tax avoidance, is used as the dependent variable. Our major interest variable is $\mathrm{SUB}_{t}$ and $\mathrm{RPT}_{t}$ and we also control the financial variables that can influence corporate tax avoidance.

First, the results of the hypothesis 1 show that managers of MNCs with overseas subsidiaries aggressively carried out tax avoidance behaviors. Thus, there are statistically positive relation between $\mathrm{TS}_{\mathrm{t}}$ and MNCs. It means that managers of MNCs were more inclined to avoid tax than those of other firms. Furthermore, there are significantly positive relation between TS3 and RPT. In summary, the results show that companies engage in active tax avoidance behaviors by holding overseas subsidiaries or by carrying out internal transactions through related-party TP.

The last column in table 6 represents the results of hypothesis 2. The coefficient of SUB*RPT is 0.008 and significantly positive at the $5 \%$ level. It means that among MNCs with overseas subsidiaries, those that carried out many internal transactions through overseas related-party TP showed a higher propensity to avoid tax. When observing the other control variables that can influence corporate tax avoidance shown in Table 6 below, SIZE presents a significantly positive relation with TS3 at the $1 \%$ level. This appears to be due to the abundant resources possessed by large corporations, which that can be used to influence the political process to the firm's advantage and to organize corporate activities to avoid tax (Siegfried 1974; Choi et al. 2011). On the other hand, tax avoidance $\left(\mathrm{TS}_{\mathrm{t}}\right)$ shows a significantly positive relation with the control variables $\mathrm{LEV}_{t}$ and $\mathrm{ROA}_{t}$ and a negative relation with FORN $_{\mathrm{t}}$, thus presenting results similar to those in Table 5.

In summary, the results of Table 6 show a significantly positive relation between MNCs and the manager's propensity to avoid tax, thus showing that managers of MNCs aggressively carried out tax avoidance behaviors. On the other hand, among MNCs with overseas subsidiaries, those that carried out more foreign-related party transactions showed a higher propensity to avoid tax. This implies that MNCs pursue aggressive tax avoidance strategies by adjusting transfer prices between foreign-related parties. 
Table 6. The Regression Analysis of Tax Avoidance Using TS3

\begin{tabular}{|c|c|c|c|c|c|c|c|}
\hline Variables & Exp. Sign & Coeffs & $(t-s t a t)^{a}$ & Coeffs & $(t-s t a t)^{a}$ & Coeffs & $(t-s t a t)^{a}$ \\
\hline Intercept & $+/-$ & -0.057 & $(-4.8)^{* * *}$ & -0.054 & $(-4.51)^{* * *}$ & -0.054 & $(-4.53)^{* * *}$ \\
\hline$S U B_{\mathrm{t}}$ & + & 0.001 & $(1.95)^{*}$ & & & 0.006 & $(1.85)^{*}$ \\
\hline$R P T_{\mathrm{t}}$ & + & & & 0.004 & $(2.77)^{* *}$ & 0.004 & $(2.49)^{* *}$ \\
\hline$S U B_{\mathrm{t}} * R P T_{\mathrm{t}}$ & + & & & & & 0.008 & $(2.43)^{* *}$ \\
\hline$S I Z E_{\mathrm{t}}$ & $+/-$ & 0.002 & $(3.84)^{* * *}$ & 0.002 & $(3.36)^{* * *}$ & 0.002 & $(3.37)^{* * *}$ \\
\hline$L E V_{\mathrm{t}}$ & - & 0.013 & $(2.46)^{* *}$ & 0.013 & $(2.39)^{* *}$ & 0.013 & $(2.47)^{* *}$ \\
\hline$R O A_{\mathrm{t}}$ & + & 0.124 & $(6.4)^{* * *}$ & 0.125 & $(6.44)^{* * *}$ & 0.125 & $(6.42)^{* * *}$ \\
\hline$P P E_{\mathrm{t}}$ & + & -0.002 & $(-0.32)$ & -0.001 & $(-0.15)$ & -0.001 & $(-0.22)$ \\
\hline$O C F_{\mathrm{t}}$ & - & -0.011 & $(-1.0)$ & -0.011 & $(-0.99)$ & -0.011 & $(-0.99)$ \\
\hline$F O R N_{\mathrm{t}}$ & - & -0.000 & $(-4.4)^{* * *}$ & -0.000 & $(-4.55)^{* * *}$ & -0.000 & $(-4.58)^{* * *}$ \\
\hline$I N V_{\mathrm{t}}$ & + & 0.028 & $(0.73)$ & 0.027 & $(0.71)$ & 0.029 & $(0.76)$ \\
\hline$I N T A N_{\mathrm{t}}$ & + & 0.031 & $(2.12)^{*}$ & 0.032 & $(2.11)^{*}$ & 0.032 & $(2.14)^{*}$ \\
\hline$M T B_{\mathrm{t}}$ & - & -0.001 & $(-1.01)$ & -0.001 & $(-0.92)$ & -0.001 & $(-0.93)$ \\
\hline SYEAR & & \multicolumn{2}{|c|}{ Included } & \multicolumn{2}{|c|}{ Included } & \multicolumn{2}{|c|}{ Included } \\
\hline$\sum I N D$ & & \multicolumn{2}{|c|}{ Included } & \multicolumn{2}{|c|}{ Included } & \multicolumn{2}{|c|}{ Included } \\
\hline Adj. $R^{2}$ & & \multicolumn{2}{|c|}{0.245} & \multicolumn{2}{|c|}{0.244} & \multicolumn{2}{|c|}{0.245} \\
\hline
\end{tabular}

The dependent variable is $\mathrm{TS}_{\mathrm{t}}$. $\mathrm{TS}_{\mathrm{t}}$ is tax avoidance calculated as tax subsidy on equity. $\mathrm{SUB}_{\mathrm{t}}$ is a dummy variable that equals 1 if a firm has overseas subsidiaries, and 0 otherwise. $\mathrm{RPT}_{\mathrm{t}}$ is total transactions to the related-party sales scaled by total sales. SIZE $\mathrm{t}_{\mathrm{t}}$ is $\log$ of total assets. $\mathrm{LEV}_{\mathrm{t}}$ is debt-assets. $\mathrm{ROA}_{\mathrm{t}}$ is return-on-assets, net income scaled by average total assets. $\mathrm{PPE}_{t}$ is property, plant and equipment scaled by average total assets. $\mathrm{FORN}_{\mathrm{t}}$ is the percentage of common shares held by foreign investors. $\mathrm{INV}_{\mathrm{t}}$ is acquisition of machinery and equipment scaled by average total assets. INTAN ${ }_{t}$ is intangible asset scaled by average total assets. $\mathrm{MTB}_{\mathrm{t}}$ is market-to-book ratio. The sample consists of 4,585 non-financial firm-years that are traded over Korean Stock Exchange for 2001-2010 with non-missing data collected from KIS-Value database. ${ }^{a *, * *},{ }^{* * *}$ is two-tailed t-test with t-statistics adjusted for clustering of standard errors by firm and year, significant at less than $10 \%, 5 \%$, and $1 \%$ levels, respectively.

\section{CONCLUSION}

This study verified whether additional tax avoidance effects exist in relation to the overseas subsidiaries of MNCs. The following summarizes the results of the empirical analysis conducted with 4,585 Korean firms from 2001 to 2010 by company and year. First, we find that tax avoidance generally increases among MNCs that are internationally diversified through the possession of overseas subsidiaries. In other words, the results show a positive relation between globally diversified MNCs and corporate tax avoidance. This is likely due to the firms' use of aggressive tax strategies appropriate to the various countries in which they have expanded their businesses. Second, we also find that MNCs use overseas TP behaviors to avoid tax actively when compared to firms without overseas subsidiaries. Thus, the corporate tax avoidance strategies of the parent company were increased by their adjustments of sales and purchase prices through actual transactions.

This study differs from previous literatures in the following respects. First, most studies researching the effects of FDI through overseas subsidiaries on corporate tax avoidance mainly analyzed companies that are headquartered in an advanced nation. However, this study analyzes the effects of FDI through overseas subsidiaries on the management's propensity to avoid tax by studying Korean companies that have the traits of both developed and emerging markets. Second, previous studies related to FDI and tax law most typically studied tax rates and investments, whereas tax havens have been the main topic of research in relation to tax avoidance. On the other hand, this study provides empirical evidence of related theories through research conducted on tax avoidance through normal transactions. Lastly, this study enhances the robustness of earlier results using various tax avoidance measurements. This study uses the traditional tax avoidance measurement (GAAP ETR) and the D\&D (2006) model to verify the effects of tax avoidance through FDI. Robustness is also verified through the W\&L model.

This study holds significance in that it showed how FDI and overseas TP behaviors through foreign subsidiaries can be used by companies to avoid tax. This also explains why MNCs are recently increasing their efforts by to build 
additional local production factories. In this sense, this study has important implications that should be noted by national governments hoping actively to attract companies in the future.

\section{AUTHOR BIOGRAPHIES}

Dr. Sung Jin Park is an assistant professor at the department of business administration, Sungshin Women's University. His research focuses on financial accounting, auditing, management information system, management $\&$ cost accounting, taxation. (1st author)

Dr. Woo Jin Park is an assistant professor at the college of Government and Business, Yonsei University. His research focuses on International Financial Reporting Standards(IFRS), Continuous Auditing Systems, R\&D investment in IT industry, strategic management information systems, project management, international taxation and accounting. (corresponding author)

Dr. Eun Jung Sun is an assistant professor at Hannam University. Research interests included management information system, management \& cost accounting, and government accounting. (co-author)

Sohee Woo is an assistant professor at Woosong University in Korea. Research interests included auditing, corporate governance, financial management and capital market in accounting. (co-author)

\section{REFERENCES}

Ahn, M. K., S. M. Bae, and D. J. Yang (2012). The Effect of Firm Internationalization on Discretionary Accounting Choices, Korea Business Education Review 27, 99-125.

Ahn, S. C., (1996). Tax Burdens and Firm Characteristics, Korea Taxation Review 8, 125-152.

Atwood, T., M. Drake, and L. Myers (2010). Book-Tax Conformity, Earnings Persistence and the Association between Earnings and Cash Flows, Journal of Accounting and Economics 50, 111-125.

Ayers, B., X. Jiang, and S. Laplante (2009). Taxable Income as a Performance Measure: The Effects of Tax Planning and Earnings Quality, Contemporary Accounting Research 26, 15-54.

Balakrishnan, K., J. Blouin, and W., Guay (2010). Does Tax Aggressiveness Reduce Financial Reporting Transparency?. Working Paper. University of Pennsylvania.

Berger, P. (1993). Explicit and Implicit Tax Effects of the R\&D Tax Credit, Journal of Accounting Research 31, $131-171$.

Cha, S. M., J. H. Chung, and Y. K. Yoo (2010) Corporate International Diversification and Cost of Equity Capital, Korea Management Review 39, 157-175.

Chen, K., X. Chen, Q. Cheng, and T. Shevlin (2010) Are Family Firms More Tax Aggressive than Non Family Firms? Journal of Financial Economics 95, 41-61.

Chen. K. P., and C. Chu, 2005, Internal Control vs. External Manipulation: A Model of Corporate Tax Evasion, Journal of Economics 36, pp. 151-164.

Cheng, C., H. Huang, Y. Li, and J. Stanfield (2012). The Effect of Hedge Fund Activism on Corporate Tax Avoidance, The Accounting Review 87, 1493-1526.

Cheon, K. A. (1997). A Study on the Effects of the Firm Characteristics on Tax Burden, Korea Accounting Review 22, 23-60.

Choi, W. W., and Y. S. Koh (2011) Related Party Transactions and Tax Avoidance, Korea Taxation Review 28, 9-35.

Chun, H. M. (2013) Corporate International Diversification and Tax Avoidance, Korea Journal of Accounting and Taxation 14, 175-197.

Chun, H. M., and H. S. Park (2014). Monitoring Role of National Pension Fund on the Corporate Tax Avoidance, Korea Taxation Review 31, 9-37.

Collins, J., D. Kemsley, and M. Lang (1998). Cross-Jurisdictional Income Shifting and Earnings Valuation, Journal of Accounting Research 36, 209-229.

Craig, C. S., and S. P. Douglas (2000) Configural Advantage in Global Markets, Journal of Interantional Marketing 8, 6-26.

Dechow, P., R. Sloan, and A. Sweeney (1995). Detecting Earning Management. The Accounting Review 70, 193-225.

Denis, D., D. Denis, and K. Yost (2002) Global Diversification, Industrial Diversification and Firm Value, Journal of Finance 57, 1951-1980.

Desai, A., and D. Dharmapala (2009). Corporate Tax Avoidance and Firm Value, Review of Economics and Statistics 91, 537546.

Desai, M. A., and D. Daharmapala (2006). Corporate Tax Avoidance and High Powered Incentive, Journal of Financial Economics 79, 145-179.

Dyreng, S., M. Hanlon, and E. Maydew (2008). Long-Run Corporate Tax Avoidance, The Accounting Review 83, 61-82.

Dyreng, S., M. Hanlon, and E. Maydew (2010). The Effects of Executives on Corporate Tax Avoidance, The Accounting Review 
$85,1163-1189$.

El Mehdi, K., and S. Seboui (2011). Corporate Diversification and Earnings Management, Review of Accounting and Finance 10, 176-196.

Foley, C., J. Hartzell, S. Titman, and G. Twite (2007). Why Do Firms Hold So Much Cash? A Tax-Based Explanation, Journal of Financial Economics 86, 576-607.

Geringer, J. M., S. Tallman, and D. M. Olsen. (2000). Product and International Diversification among Japanese Multinational Firms. Strategic Management Journal 21, 51-80.

Goh, J. K. (1997). The Study on Measurement of Tax Burden, Korea Accounting Review 22, 51-82.

Graham, R., and A, Tucker (2006). Tax Shelters and Corporate Debt Policy, Journal of Financial Economics 81, 563-594.

Grubert, H., T. Goodspeed, and D. Swenson (1993). Explaining the Low Taxable Income of Foreign Controlled Compnies in the United States. Studies in International Taxation, University of Chicago Press.

Grubert, H., and J. Mutti (1991). Taxes, Tariffs and Transfer Pricing in Multinational Corporate Decision Making, Review of Economic and Statistics 73, 285-293.

Hanlon, M. (2005) The Persistence and Pricing of Earnings, Accruals and Cash Flows when Firms Have Large Book-Tax Differences, The Accounting Review 80, 137-166.

Hanlon, M., and S. Heitzman ( 2010). A Review of Tax Research, Journal of Accounting and Economics 50, 127-178.

Harris, D. G. (1993). The Impact of U.S. Tax Law Revision on Multinational Corporations'Capital Location and Income-Shifting Decision, Journal of Accounting Research 31, 111-140.

Harris, D., R. Morek, J. Slemrod and B.Yeung. (1994). Income Shifting in U.S. Multinational Corporations. Studies in International Taxation. University of Chicago Press.

Harris, M., C. Kriebel, and A. Raviv (1982). Asymmetric Information, Incentives and Intra-firm Resource Allocation, Management Science 28, 604-620.

Hitt, M. A., R. E. Hoskisson, and H. Kim (1997). International Diversification: Effects on Innovation and Firm Performance in Product-Diversified Firms, Academy of Management Journal 40, 67-98.

Hong, Y. N., J. K. Park, and K. Y. Lee (2009). Managerial Ownership and Distinctive Properties of Tax Avoidance Strategy, Korea Taxation Review 26, 125-147.

Hughes, L., D. Logue, and R. Sweeny (1975). Corporate International Diversification and Market Assigned Measure of Risk and Diversification, Journal of Financial Risk and Diversification 10, 627-637.

Jacob, J. (1996). Taxes and Transfer Pricing: Income Shifting and the Volume of Intrafirm Transfers, Journal of Accounting Research 34, 301-312.

Jiang, X., K. Sen, and A. Stephen (2008). Global Diversification and Cost of Equity. Working Paper. University of Cincinnati.

Jiraporn, P., Y. Kim, and I. Mathur (2008). Does Corporate Diversification Exacerbate or Mitigate Earnings Management? : An Empirical Analysis. International Review of Financial Analysis 17, 1087-1109.

Joos, P., J. Pratt, and S. D. Young (2002). Using Deferred Taxes to Infer the Quality of Accruals, Working Paper, MIT.

Jung, H. (2011). The Effect of the CSR Performing Level on Tax Avoidance, Master's Thesis. University of Konkuk.

Jung, I. S. (2003). A Study of the Relationship between International Diversification and Organizational Performance among Korean Exporters, Korea Journal of Trade 28, 139-155.

Jung, Y. S., Y. W. Lee, and Y. H. Cho (2011). The Effect of Corporate Governance on Tax Aggressiveness, Korea Taxation Review 28, 9-40.

Kang, J. Y., and Y. C. Kim (2012). Corporate Tax Avoidance and Ownership Structure, Korea Taxation Review 29 , 37-67.

Ki, E. S. (2012). The Effect of Corporate Social Responsibility on the Tax Avoidance and the Market Response to the Tax Avoidance, Korea Taxation Review 29, 107-136.

Kim, J. B., Y. Li, and L. Zhang (2011) Corporate Tax Avoidance and Stock Price Crash Riskpp. Firm-Level Analysis, Journal of Financial Economics 100, 639-662.

Kim, J. H., and J. W. Jeong ( 2006). The Effect of Corporate Financial Characteristics on Tax Avoidance, Korea Taxation Review 23, 97-123.

Kim, M. I., H. T. An., and J. D. Kim (2012). The Impact of International Diversification on Value Relevance of Earnings, Korea Accounting Review 37, 157-193.

Klassen, K., M. Lang, and M. Wolfson (1993). Geographic Income Shifting by Multinational Corporateions in Response to Tax Rate Changes, Journal of Accounting Research 31, 141-173.

Klassen, K., J. Pittman, and M. Reed (2004). A Cross-National Comparison of R\&D Expenditure Decision: Tax Incentives and Financial Constraints, Contemporary Accounting Research 21, 639-684.

Kogut, B. (1983). Foreign Direct Investment as a Sequential Process, The Multinational Corporation in the 1980s. MIT Press.

Kogut, B. (1985). Designing Global Strategies: Profiting from Operational Flexibility, Sloan Management Review 27, $27-38$.

Kogut, B., and U. Zander (1993). Knowledge of the Firm and the Evolutionary Theory of the Multinational Corporation, Journal of International Business Studies 24, 625-645.

Ko, J. K., S. S. Yoon, J. Y. Kang, and K. S. Lee (2013). A Review of Tax Research, Korean Accounting Review 38, $367-446$.

Koh, S. S., and S. S. Park (2011). A Study on the Difference of Tax Avoidance Before and After Tax Investigation, Korea Taxation Review 28, 41-65.

Koh, Y. S., and H. W. Paik (2010). Family Firms and Corporate Avoidance, Korea Taxation Review 27, 49-76. 
Koh, Y. S., J. H. Kim, and W. W. Choi (2007). A Study on Corporate Tax Avoidance, Korea Taxation Review 24, 9-40.

Krugman, P. (1991). Geography and Trade. Cambridge, MA. MIT Press.

Kwok, T. W. (2001) Tax Law 1st. Bobmunsa Co.

Lee, B. S., and J. H. Jung (2008). The Reaction of the Stock Market according to Tax Avoidance, Korea Taxation Review 25, 139-168.

Lee, C. H. (2003) International Diversification, Product Diversification, Organizational Learning, Their Interactions and Firm Value, Korea Management Review 32, 1291-1315.

Lee, H. J., H. U. Jung., and K. I. Lee (2013). The Effect of Ownership Wedge on Effective Tax Rates, Korea Journal of Accounting and Taxation 14, 9-30.

Lee, K. B. (2010). The Effects of a Firm's Ownership Structure on Tax Avoidance, Korea International Accounting Review 34, 187-216.

Lo, A., R. Wong and M. Firth, 2010, Tax, Financial Reporting, and Tunneling Incentive for Income Shifting : An Empirical Analysis of the Transfer Pricing Behavior of Chinese-Listed Companies, Journal of the American Taxation Association $32,1-26$.

Manzon, G. B. Jr., and G. A. Plesko (2002). The Relation between Financial and Tax Reporting Measures of Income, Tax Law Review 55, 175-214.

Morck, R., and B. Yeung (1998) Why Investors Sometimes Value Size and Diversification: The Internalization Theory on Synergy, Working Paper. Institute for Financial Research. University of Alberta.

Noh, H. S. (2003). Determinants of the Variability in Effective Tax Rates in Response to Corporate Tax Rate Reduction, Korea Taxation Review 20, 101-125.

Oh, K. W., D. H. Lee, and M. W. Lee (2008). The Tax Avoidance by Ownership Structure of Firms with Stock Option, Korea Journal of Accounting 17, 65-95.

Park, C. R. (1999). Firm's Characteristics and Tax Avoidance, Korea Accounting and Information Review 11, 25-41.

Park, J. K., and Y. E. Hong (2009). Corporate Tax Avoidance and Foreign Ownership, Korea Taxation Review 26, 105-135

Park, M. Y. (2012). Auditor`s Characteristics and Tax Avoidance, Korea Journal of Accounting and Taxation 13, $191-219$.

Park, S, S., G. I. Jang, G. K. Jung, and S. T. Bae (2006) An Empirical Study on the Relationship between Corporate Governance and Earnings Management, Korea Accounting and Information Review 24, 213-241.

Philips, J., M. Pincus, and S. Rego (2003). Earnings Management:. New Evidence Based on Deferred Tax Expense, The Accounting Review 78, 491-521.

Porcano, T. M. (1986). Corporate Tax Rate: Progressive, Proportional or Regressive, The Journal of the American Taxation Association, 17-31.

Porter, M. E., 1990, The Competitive Advantage of Nations, New York. Free Press.

Robinson, J., S. Sikes, and C. Weaver (2010). Performance Measurement of Corporate Tax Departments, The Accounting Review 85, 1035-1064.

Rossing, C. P. (2013). Tax strategy control: The case of transfer pricing tax risk management, Management Accounting Research 24, 175-194.

Shawn, A. S., D. H. Yang, S. S. Lee, and K. S. Kim (2012). A Study on the Effect of Corporate Governance Structure on the Relationship between Tax Sheltering and Firm Value, Korea Journal of Accounting and Taxation 13, 385-419.

Shin, S. M. (2005). Causality Between Effective Tax Rate and Debt Ratio, and Effectiveness of the Tax Provision for Limiting Tax Deductibility of Interest Expense, Korea Accounting Review 30, 77-108.

Siegfried, J. (1974). Effective Average U.S. Corporate Income Tax Rates, National Tax Journal 27, 58-79.

Stickney. C., and V. McGee (1982). Effective Corporate Tax Rates the Effect of Size, Capital Intensity, Leverage and Other Factors, Journal of Accounting and the Public Policy 4, 125-152.

Wang, S. W. (1991). The Relation between Firm Size and Effective Tax Rates: A Test of Firms' Political Success, The Accounting Review 66, 158-169.

Wiikie, P. J., and S. T. Limberg (1993). Measuring Explicit Tax (Dis)Advantage for Corporate Taxpayers: An Alternative to Average Effective Tax Rates, The Journal of the American Taxation Association 15, 46-71.

Wilson, R. (2009). An Examination of Corporate Tax Shelter Participants, The Accounting Review 84, 969-999.

Yoo, Y. K., H. H. Kim, and H. M. Chun (2014) Corporate International Diversification and Real Earnings Management. Korea Accounting Review 39, 293-322.

Yoo, Y. K., S. M. Cha, and J. H. Chung (2010). Corporate International Diversification and Cost of Equity Capital: Korean Evidence, Korea Management Review 39, 157-175.

Zimmerman, J. L. (1983). Taxes and Firm Size, Journal of Accounting and Economics 12, 119-149. 


\section{NOTES}

